\title{
DAMPAK MEDIA ONLINE TERHADAP PERILAKU SOSIAL MASYARAKAT KOTA PAREPARE
}

\author{
Nurlina \\ Prodi KPI IAIN Parepare
}

\section{PENDAHULUAN}

Kita hidup di lingkungan media yang sedang berubah denga cepat. Hanya beberapa tahun yang lalu, sebagian besar orang tidak pernah mendengar multimedia atau Internet. Sekarang, Anda hampir tidak bisa membaca koran tanpa melihat salah satu atau keduanya.

Bentuk perubahan yang terjadi pada lingkungan media banyak macamnya, dalam hal tertentu, sangat luar biasa. Koran mengalami penurunan jumlah pembaca pada waktu tertentu. Perkembangan teknologi informasi membawa sebuah perubahan dalam masyarakat. Lahirnya media sosial menjadikan pola perilaku masyarakat mengalami pergeseran baik budaya, etika dan norma yang ada. Indonesia dengan jumlah penduduk yang besar dengan berbagai kultur suku, ras dan agama yang beraneka ragam memiliki banyak sekali potensi perubahan sosial. Dari berbagai kalangan dan usia hampir semua masyarakat Indonesia memiliki dan menggunakan media sosial sebagai salah satu sarana guna memperoleh dan menyampaikan informasi ke publik.

Media sosial adalah sebuah media online, dengan para penggunanya bisa dengan mudah berpartisipasi, berbagi, dan menciptakan isi meliputi blog, jejaring sosial, wiki, forum dan dunia virtual. Blog, jejaring sosial dan wiki merupakan bentuk media sosial yang paling umum digunakan oleh masyarakat di seluruh dunia. Dinamika kehidupan masyarakat mengalami perkembagan yang sangat pesat. 
Akulturasi budaya dengan sentuhan teknologi informasi merupakan fenomena pendorong perubahan tersebut. Kebiasaan personal dalam menyampaikan ide, kritik, saran dan bahkan "hujatan" sering dijumpai setiap jam dan hari melalui berbagai varian media yang digunakan.

Orang yang pertama kali sukses menghubungkan internet di Indonesia adalah Joseph Luhukay. Dia adalah seorang pakar komputer dan ekonomi yang berhasil mengembangkan jaringan Uinet di beberapa Universitas di Indonesia. Beliau kemudian mencetak prestasi dengan menhubungkan jaringan internet yang ada di Indonesia agar masuk ke ranah global pada kisaran tahun 1984-an.

Setelah itu muncullah PT. Indo Internet dan PT. Pos Indonesia yang mengembangkan Wasantara Network. Kemudian ada pula Indosatnet dan Telkomnet yang bergerak di bidang penyedia jasa ISP (Internet Service Provider). Meski penggunanya tergolong banyak namun tidak menjadikan indikasi penyebaran internet di Indonesia menyebar secara merata. Hal ini dikarenakan ISP hanya mampu diakses oleh kalangan tetrtentu yang sudah memiliki komputer dan mampu membayar tagihan telepon.

Pada Tahun 2017, pengguna PC bebasis Cloud sudah menjamur diiringi dengan munculnya laptop serta Mobile Cloud yang semakin berkembang dari tahun ke tahun.

Hal ini dapat dibuktikan dengan banyaknya inovasi dan penemuan yang sederhana hingga sangat rumit. Bahkan, kurang dari 10 tahun terakhir, teknologi handphone yang awalnya hanya sebuah alat komunikasi nirkabel berkembang menjadi alat komunikasi yang dapat mengambil foto, merekam video, mendengarkan musik, dan mengakses internet dalam hitungan detik. Perilaku manusia adalah sekumpulan perilaku yang dimiliki oleh manusia dan dipengaruhi oleh adat, sikap, emosi, nilai, etika , kekuasaan, persuasi, dan genetika. 
Seiring berjalannya waktu dan berkembangnya internet serta dilihat dari perilaku seseorang dapat dikelompokkan ke dalam perilaku wajar, perilaku dapat diterima, perilaku aneh, dan perilaku menyimpang. Dalam sosiologi, perilaku dianggap sebagai sesuatu yang tidak ditujukan kepada orang lain dan oleh karenanya merupakan suatu tindakan sosial manusia yang sangat mendasar. Nilai sosial adalah nilai yang dianut oleh suatu masyarakat, mengenai apa yang dianggap baik dan apa yang dianggap buruk oleh masyarakat.

Untuk menentukan sesuatu itu dikatakan baik atau buruk, pantas atau tidak pantas harus melalui proses menimbang. Hal ini tentu sangat dipengaruhi oleh kebudayaan yang dianut masyarakat. Tak heran apabila antara masyarakat yang satu dan masyarakat yang lain terdapat perbedaan tata nilai. Setiap masyarakat dalam kehidupannya pasti mengalami perubahan-perubahan.

Berdasarkan sifatnya, perubahan yang terjadi bukan hanya menuju ke arah kemajuan, namun dapat juga menuju ke arah kemunduran. Perubahan social yang terjadi memang telah ada sejak zaman dahulu. Ada kalanya perubahan-perubahan yang terjadi berlangsung demikian cepatnya, sehingga membingungkan manusia yang menghadapinya.

Kota parepare yang terbilang sebagai kota yang mulai berkembang dari aspek-aspek pembangunan, teknologi, pengetahuan, pendidikan, dan lain-lain. Sangat berpeluang menjadi titik perkembagan teknologi media online. berdasarkan yang terjadi beberapa saat yang lalu tentang viralnya "om telolet om" dan istilah "Hai Tayo" yang tiba- tiba berkembang dikalangan masyarakat tidak memandang apakah itu anak-anak dan kalangan dewasa membawa dampak yang terkesan berkembang sangat cepat. Tidak terlepas lagi dari peristiwa tentang "Gerakan 212" yang begitu sering diberitakan baik di media massa maupun di internet. 
Hanya dua kemungkinan yaitu, pengaruh positif dan pengaruh negatif. Ketika media online digunakan ke hal-hal yang positif maka tentunya akan berdampak positif pula terhadap pengguna media online. Begitupun sebaliknya apabila media online digunakan hal yang negatif maka akan berdampak negatif pula bagi pengguna media online.

\section{REFERENCES}

(1) Abdullah, B. (2016) 'KONSTITUSI PENDIDIKAN ISLAM DALAM MEMBANGUN MASYARAKAT MADANI', KURIOSITAS: Media Komunikasi Sosial Keagamaan, 9(2), pp. 79-86.

(2) Ahdar, A. (2017) 'TINJAUAN KRITIS DAN MENYELURUH TERHADAP FUNDAMENTALISME DAN RADIKALISME ISLAM MASA KINI', KURIOSITAS: Media Komunikasi Sosial dan Keagamaan, 10(1), pp. 19-36.

(3) Al-Amri, L. and Haramain, M. (2017) 'AKULTURASI ISLAM DALAM BUDAYA LOKAL', KURIOSITAS, 10(2), pp. 87-100.

(4) Al-Khalidy, Shalah 'Abd al-Fattah. 2000. Ma'a Qishash al-Sabikin fiy al-Qur'an, ditrerjemahkan oleh Setiawan Budi Utomo dengan judul Kisah-kisah Al-Qur'an: Pelajaran dari Orang-orang Dahulu. Cet. I; Jakarta: Gema Insani Press.

(5) Al-Maragiy, Ahmad Mushthafa.Tafsiral-Maragiy. Bairut: Dar al-Fikr, t.th.

(6) Al-Maududi, Abul A'la. 1986. Pengertian Agama, Ibadah dan Ketuhanan Yang Maha Esa dalam Al-Qur'an, diterjemahkan oleh Mahyuddin Syaf tanpa menyebut judul aslinya. Cet. I; Bandung: Sinar Baru.

(7) Al-Qaththan, Manna'. Mabahif fiy 'Ulum al-Qur'an.Bairut : Muassasah alRisalah, t.th.

(8) Al-Qurthubiy, Abiy 'Abdillah Muhammad ibn Ahmad al-Anshariy.Al-Jami' li Ahkam al-Qur'an. Bairut: Dar al-Fikr li al-Thaba'ah wa al-Nasyr wa al-Tauzi', t.th.

(9) Al-Shabuniy, Muhammad 'Aliy. Shafwah al-Tafasir.Kairo: Dar al-Fikr, t.th.

(10) Anwar, A. (2016) 'KONTRIBUSI KELUARGA TERHADAP PEMBENTUKAN KARAKTER ANAK (Studi Perspektif Modal Sosial di Kota Parepare)', KURIOSITAS, 9(1), pp. 57-65.

(11) Arikunto Suharsimi 1998, Prosedur Penelitian Suatu Pendekatan Praktek. Cet II Jakarta: PT. Rineka Cipta.

(12) Azis, A. and Jufri, M. (2017) 'IMPLEMENTASI NILAI-NILAI AJARAN TAU LOTANG TERHADAP MASYARAKAT LOKAL WATTANG BACUKIKI KOTA PAREPARE', KURIOSITAS: Media Komunikasi Sosial dan Keagamaan, 10(2), pp. 23-41.

(13) Azis, S. A., Herdah, H. and Jufri, M. (2016) 'IMPLEMENTASI MODEL PEMBELAJARAN KOOPERATIF MAHASISWA PROGRAM STUDI BAHASA ARAB STAIN PAREPARE (Studi Pengembangan Pembelajaran Mata Kuliah Serumpun)', KURIOSITAS, 9(1), pp. 81-102. 
(14) Azra, Azyumardi (ed.). 1999. Sejarah dan 'Ulum al-Qur'an. Cet.I; Jakarta: Pustaka Firdaus.

(15) Bisri, A. Mustofa. 2000. "Taat, Ibadah, dan Taqarrub (Bebas Menyendiri dengan Diri Sendiri)", dalam Nurcholish Madjid, et al., Puasa: Titian Menuju Rayyan.Cet. I; Yogyakarta: Pustaka Pelajar.

(16) Budiman, B., Musyarif, M. and Firman, F. (2016) 'IDEOLOGI BULETIN DAKWAH AL-ISLAM DALAM KAJIAN WACANA KRITIS', KURIOSITAS, 9(1), pp. 21-34.

(17) Chazawi,Adami. 2002. Pelajaran Hukum Pidana Bagian Ketiga.Cet. I; Jakarta: PT Raja Grafindo Persada.

(18) Hamka. 1992. Tafsir al-Azhar. Jakarta: PT Pustaka Panjimas.

(19) Haramain, M. (2012) 'Pemikiran dan Gerakan Dakwah Tuan Guru M. Zainuddin Abdul Madjid di Lombok NTB'. Makassar: Universitas Islam Negeri Alauddin Makassar.

(20) Haramain, M. (2016) 'al-Wasathiyyah wa Atsaruha fi al-da'wah al-Islamiyyah: Dirasah Lugawiyyah Manhajiyyah', Langkawi: Journal of The Association for Arabic and English, 2(1), pp. 83-100.

(21) Haramain, M. (2017) 'DAKWAH DALAM ARUS GLOBALISASI MEDIA: PELUANG DAN TANTANGAN', KOMUNIDA: MEDIA KOMUNIKASI DAN DAKWAH, 7(1), pp. 60-73.

(22) Haramain, M. (2019) Prinsip-prinsip Komunikasi dalam al-Qur'an. Parepare: IAIN Parepare Nusantara Press.

(23) Hidayat, W. (2016) 'PERSEPSI SISWA SMA KOTA PAREPARE TENTANG STAIN PAREPARE', KURIOSITAS: Media Komunikasi Sosial Keagamaan, 9(1), pp. 49-56.

(24) Ilham, M. I. M. (2017) 'HERMENEUTIKA AL-QUR'AN', KURIOSITAS: Media Komunikasi Sosial dan Keagamaan, 10(2), pp. 101-119.

(25) Ipandang, I. (2017) 'FILSAFAT AKHLAK DALAM KONTEKS PEMIKIRAN ETIKA MODERN DAN MISTISISME ISLAM SERTA KEMANUSIAAN', KURIOSITAS: Media Komunikasi Sosial dan Keagamaan, 10(1), pp. 1-18.

(26) Juddah, A. B. (2015) 'ANALITIS SINTETIK TERHADAP STRATEGI PEMBELAJARAN ANDRAGOGI BERPERSPEKTIF KEMANDIRIAN DOSEN DALAM PEMBELAJARAN', Kuriositas: Media Komunikasi Sosial dan Keagamaan, 8(2), pp. 41-45.

(27) Khairul, K. and Haramain, M. (2018) 'Aplikasi Digital Risalah Ilmu Tajwid dalam Meningkatkan Kemampuan Baca Al Qur'an', KURIOSITAS: Media Komunikasi Sosial dan Keagamaan, 11(2), pp. 145-157.

(28) Mahfud,Sahal. 2000. "Ibadah Sosial Tentukan Kualitas Iman", dalam Nurcholish Madjid, et al., Puasa: Titian Menuju Rayyan.Cet. I; Yogyakarta: Pustaka Pelajar.

(29) Marpaung, Leden. 1991. Unsur-unsur Perbuatan yang Dapat Dihukum (Delik). Cet. I; Jakarta: Sinar Grafika.

(30) Muammar, M. and Suhartina, S. (2018) 'Media Pembelajaran Berbasis Teknologi Informasi Dalam Meningkatkan Minat Belajar Akidah Akhlak', KURIOSITAS: Media Komunikasi Sosial dan Keagamaan, 11(2), pp. 176-188.

(31) Mulianah, S. and Hidayat, W. (2016) 'PENGEMBANGAN TES BERBASIS KOMPUTER', KURIOSITAS: Media Komunikasi Sosial dan Keagamaan, 9(2), pp. 27-43.

(32) Muliati, M. (2016) 'PENGARUH PAHAM KEAGAMAAN TERHADAP ETOS KERJA PEDAGANG PASAR SENTRAL KABUPATEN PINRANG', KURIOSITAS: Media 
Komunikasi Sosial Keagamaan, 9(2), pp. 101-115.

(33) Munawwir, Ahmad Warson.Al-Munawwir: Kamus Arab-Indonesia.Yogyakarta: Pondok Pesantren al-Munawwir, t.th.

(34) Quthub, Sayyid. 1971. Fiy "ilal al-Qur'an. Cet. VII; Bairut: Mazidah wa Manqahat.

(35) Rachman, Luthfi. 2000. "Nilai Ikhlas dalam Puasa Ramadhan", dalam Nurcholish Madjid, et al.Puasa: Titian Menuju Rayyan.Cet. I; Yogyakarta: Pustaka Pelajar.

(36) Rahmawati, R., Wahidin, W. and Aris, A. (2015) 'MATERI FIQH IBADAH DAN IMPLEMENTASINYA BAGI MAHASISWA JURUSAN SYARIAH STAIN PAREPARE', KURIOSITAS: Media Komunikasi Sosial Keagamaan, 8(1), pp. 71-86.

(37) Shihab,M. Quraish. 1992. Membumikan Al-Qur'an: Fungsi dan Peran Wahyu dalam Kerhidupan Umat.Bandung: Mizan.

(38) Sunubi, A. H., Dalle, A. and Maghdalena, M. (2016) 'ENGLISH TEACHER INSTRUCTION IN GIVING MATERIAL BY USING CODE SWITCHING AND CODE MIXING IN SMU NEG. 2 PAREPARE', KURIOSITAS, 9(1), pp. 35-47.

(39) Tanwir, T. and Said, H. (2018) 'Inovasi Pembelajaran Guru Pendidikan Agama Islam Berbasis Teknologi Informasi', KURIOSITAS: Media Komunikasi Sosial dan Keagamaan, 11(2), pp. 189-210.

(40) Ulum, A. C. and Haramain, M. (2017) 'EKSISTENSI DAKWAH DALAM MERESPON PLURALISME', KOMUNIDA: MEDIA KOMUNIKASI DAN DAKWAH, 7(2), pp. 124138. 